\title{
Fikri Mülkiyet Hakları ve Mülkiyete İlişsin Teorik Yaklaşımlar
}

\section{Yavuz YAYLA ${ }^{l}$}

\section{Intellectual Property Rights and Theoretical Approaches to Property}

\begin{tabular}{l} 
ARTICLE INFO \\
\hline Article History: \\
Date Submitted: 28.01 .2020 \\
Date Accepted: 30.04 .2020 \\
\hline JEL Classification: \\
O34, \\
P14, \\
K11.
\end{tabular}

Keywords:

Intellectual Property

Rights,

Property Rights,

Patent

\begin{abstract}
At a side of the debate on intellectual and industrial rights are those who advocate that these rights are developed as a result of the special abilities and work of individuals and therefore that these rights are protected, while at other side of the debate are those who advocate that information is public, that information production is not possible without societal memory, and that historically the origin of this debate is identical to the history of property rights, and the debate has not lost its place on the agenda. In this study, theoretical approaches to justifying property rights and especially intellectual property rights are discussed and examined. In this context, theories about justifying patent protection will be discussed first. Then, how the concept of ownership, which is the origin of the debate, is defended and criticized in the literature will be examined in connection with intellectual property rights.
\end{abstract}

\footnotetext{
${ }^{1}$ Samsun Ondokuz Mayıs Üniversitesi İktisat Bölümü, yavuzyayla@gmail.com
} 


\section{Özet}

Fikri ve sınai haklar üzerine yürütülen tartışmanın bir yanında bu hakların bireylerin özel yetenek ve çalışmalarının sonucunda geliştiğini ve bu nedenle bu hakların korunmasını savunanlar yer alırken tartışmanın diğer yanında bilginin kamusal olduğu, toplumsal hafiza olmadan bilgi üretiminin de mümkün olmadığı ve bu nedenle kamusal ürün olarak kabul edilmesini savunanlar yer almaktadır. Tarihsel olarak bu tartışmanın kökeni mülkiyet haklarının tarihiyle özdeştir ve tartışma canlılığını kaybetmemiştir. Bu çalışmada mülkiyet haklarının ve özellikle fikri mülkiyet haklarının haklılaştırılmasına ilişkin üretilen teorik yaklaşımlar ele alınmakta ve incelenmektedir. Bu bağlamda öncelikle patent korumasının haklılaştırılmasına yönelik kuramlar ele alınacaktır. Daha sonra ise tartışmanın kökenini oluşturan mülkiyet kavramının literatürde nasıl savunulduğu ve eleştirildiği fikri mülkiyet haklarıyla bağlantılı olarak incelenecektir.

Anahtar Kelimeler: Fikri Mülkiyet Hakları, Mülkiyet Hakları, Patent,

Jel Sinıflandırma: O34, P14, K11

\section{Giriş}

$\mathrm{Bu}$ çalışmada öncelikle fikri mülkiyet haklarının (özellikle patentlerin) haklılaştırılmasına ilişkin geliştirilen doğal haklar teorisi, tekel ödüllendirmesi teorisi ve sözleşme teorisini ele alacağız. Daha sonra bu teorilerin kurulmasına da kaynaklık eden mülkiyet teorilerini ele alacak ve son olarak özel mülkiyeti eleştiren Marx'ın bakış açısına değineceğiz.

Literatürde fikri mülkiyet hakları üzerine yapılan tartışmalar, Batılı Kapitalist toplumların ve Batının dışında kalan “Dünyanın Batılılaşması””nın (Latouche, 1989) önündeki engellerin kaldırılması doğrultusunda, insan ve doğaya ait her şeyin (emek, doğa, bilgi ve insan genomu) mülkiyet miti doğrultusunda şeyleştirilmesinin ekseninde odaklanmaktadır. 
Kapitalist toplumlarda, mülkiyet mitinin toplumun kalbine yerleşmesi, John Locke'un doğal haklar teorisi ve liberal devlet üzerine düşüncelerinden kaynaklanmaktadır ve bu tartışmalarda Drahos'un belirttiği gibi bir totem olarak durmaktadır (Drahos, 1996).

Dijitalleşen ve küreselleşen dünyada Fikri Mülkiyet Haklarının konusu, teknolojideki gelişmeler sonucu ortaya çıkan yeni bilgi teknolojisi ürünlerin yani maddi olmayan ürünlerin üzerindeki mülkiyet haklarını düzenlemeye çalışmaktır. Teknolojideki gelişmelerin ekonomik ve sosyal yaşamı dönüştürmesi sonucu "mülkiyet haklarının gerçek içeriği[nin] yasalarla yeniden tanımlanabilir, ama resmi sürekliliğin güvence altına alınması piyasa sisteminin işlerliği için mutlaka gereklidir” (Polanyi, 2007: 315). Bu gereklilik açıklamasıysa, fikri ürünlerin yaygınlaşmasıyla, mülkiyet kavramının ve liberal devletin gerekçelendirilmesinin sorgulanmasına yol açmıştır.

\section{Patent Teorileri}

Literatürde patentin haklılaştırılmasını savunmak ve patentlerin evrensel bir olgu olduğunu ispatlamak üzere farklı teoriler geliştirilmiştir. Biz bu kısımda teoride yer alan üç farklı patent teorisini ele alacağız.

\subsection{Doğal Haklar Teorisi}

Doğal haklar teorisinin varsayımına göre mucit, icadı üzerinde doğal bir hakka sahiptir ve bu nedenle devlet tarafindan temsil edilen toplum bu hakkı tanımak, korumak ve uygulanmasını sağlamakla yükümlüdür. Doğal haklar teorisi Fransız Devrimi ile ortaya çıkmış ve 1791 Fransız Patent Kanunu'yla kutsal olarak kabul edilmiştir (Mgbeoji, 2005: 3).

Wendy J. Gordon'a göre, doğal haklar teorisi zorunlu olarak kamunun haklarıyla ilgili olduğu kadar, fikri mülkiyeti yaratan emekçilerin haklarıyla da ilgilidir ve doğal hakların tesisindeki sınırlamalar dikkatle ele alındığında, doğal haklar sadece özgür ifadeyi kesen bir silah değil, aynı zamanda özgürce konuşabilmenin de olumlu bir kaynağıdır. Ayrıca Gordon'a göre, kamunun talepleri fikri mülkiyeti yaratanların talepleriyle bir çatışma halindeyse, kamunun talepleri geçerli olmalıdır (Gordon, 1993: 1535-1538) (Oguamanam, 2009). 
Saтиel A. Oddi'ye göre, eğer patent sisteminin temelinde doğal haklar teorisi varsa, bu tür bir sistemin niteliği evrenselliktir, yani her biçimdeki buluşun her yerde korunması. Böylece sistem, genelden özel uygulamalara kadar, fikirler yelpazesin tamamındaki bütün buluş biçimlerini, olanaklı olduğu ölçüde, genişçe korumalıdır. Teoride, koruma konusu, aklın herhangi bir yaratıcı buluşunu dışarıda tutmayacak kadar geniş olmalıdır (Oddi, 1996: 429). Ayrıca, evrensellik imtiyazın süresine dair bir kısıtlama olmamasını gerektirir. Patentin doğal mülkiyet hakkı varsa, enstrümantalist temel dışında bunu zaman sınırlamasıyla sulandırmanın bir gerekçesi olamaz. Somut mülkiyet, harcanmış/kullanılmış olsa bile sona ermez (Oddi, 1996: 430). Yine hakkın evrensel doğasının ayırıcı diğer bir noktası, sadece ülke sınırlarıyla kısıtlanamamasıdır, çünkü evrensellik kaynağını ulusal pozitif hukuktan değil daha yüksek bir noktadan alır. Üstelik buluşun yaratıldığı rastlantısal yerin tartışılabilirliği, buluşu yapanın uyruğu ya da patent korumasının uygulandığı ülke doğal hakkın tanınmasını etkilemez (Oddi, 1996: 430).

Samuel A. Oddi'ye göre, uygulanan patent sistemlerinin bu doğal hukuk sisteminin ideal niteliklerini karşılamaktaki başarısızlığı teorinin temel eleştirisidir. Çünkü uygulanan patent sistemleri ülke sınırları, konu ve süreyle kısıtlı olduğundan evrensel değildir. Nihai olarak, buluşu yapanın katkısı ile patent sahibine verilen ödül arasında çok küçük bir bağıntı vardır (Oddi, 1996: 430).

Ikechi Mgbeoji'ye göre ise, patent sistemi için öne sürülen doğal haklar teorisi kusurlu bir gerekçelendirmedir. Çünkü ilk olarak, fikirlerin özel mülkiyetin konusu olduğu görüşünün önsel olarak kabullenir. Olağan toplumsal ilişkiler ve deneyimlerin korunmasının ve sürdürülmesinin zor olması nedeniyle bu sorunlu bir açıklamadır. İkincisi, söz konusu teori, patentlerin bir devlet imtiyazı değil, fakat mucidin doğasından kaynaklanan bir hak olduğunu varsaymaktadır. Fakat böyle bir önerme neredeyse tüm ülkelerin patent yasaları ile getirdiği çeşitli sınırlamalar nedeniyle geçerliliğini yitirir. Söz konusu sınırlamalar genellikle patentlenebilir konular, patentlerin süresi, zorunlu lisans ve bazı buluşlar için hükümet ödeneklerine ait olabilir (Mgbeoji, 2006: 3).

Doğal haklar teorisine yöneltilen bu eleştirilere rağmen, özel olarak patent ve genel olarak fikri mülkiyet, doğal haklar teorisinin felsefi temelinin değer ya da başarısızlığı ne olursa 
olsun, bu teori dünya toplumlarını, fikri mülkiyet hakları üzerinde ülkeleri TRIPS tarafından dayatılan daha evrensel bir dünya standardına geçmeye ikna etmede büyük bir söylemsel güce sahip olmuştur. Şimdiye kadar hiç bu kadar açık söylenmemişken, anılan doğal haklar teorisi, çokuluslu şirketler (ÇUŞ) tarafından egemen olunan sanayi gruplarının stratejisinde başat söylemsel rolü oynayarak gelişmekte olan ülke hükümetlerini, GATT pazarlık sürecinde “yeterli” fikri mülkiyet koruması talep etmeye ikna etmişlerdir (Oddi, 1996: 432).

\subsection{Tekel Ödüllendirilmesi Teorisi}

Bazı Fransız hukukçularına göre, ‘doğal mülkiyet hakları'nın gündeme getirilmesinin nedeni özelde 'tekel hakkı' veya 'imtiyaz' gibi yaygınlaşmamış alternatif kavramların öne çıkarılmak istenmesidir (Machlup, 1958: 23, Oguamanam, 2009).

"Tekel ödüllendirmesi” teorisi, adaletin, ilgili hizmetlerin topluma yararyyla orantılı olarak ödüllendirmesi gerektiğini varsayar ve bu durum toplumun bu ödülün güvencesi için müdahale etmesini zorunlu kılar. Mucitler faydalı hizmetler verirler ve bunları güvence altına almanın en uygun yolu, buluşlarıyla ilgili ayrıcalıklı patent hakları biçiminde geçici tekeller sağlayarak ödüllendirmektir (Machlup, 1958: 22). Bu teoriye göre, patent sistemiyle ödüllendirme sistemi getirilmezse inovasyonun gerçekleşmesi mümkün değildir (Mgbeoji, 2006: 3).

“Tekel ödüllendirmesi” teorisi, özellikle diğer tekel türlerine karşı olan İngiliz ekonomistler tarafından da şiddetle desteklenmiş ve buluş̧̧ulara verilen geçici tekelleri bir ödül olarak görmüşlerdir (Machlup, 1958: 23).

Tekel ödüllendirmesi teorisiyle ilgili problemler aslında kâr üzerinedir (Mgbeoji, 2006: 3). Endüstriyel ilerlemeyi arzulanan bir olgu olarak gören 'Tekel - kâr - teşvik' tezi gereği kapitalistler rekabetçi sömürünün sahip olduğu teknik bilginin kârı elverişli kılacağı beklentisi içerisindedirler ve bunun yerine getirilmesinin en basit, ucuz ve etkili yolu buluşlara, ayrıcalıklı patent hakları biçiminde geçici tekeller verilmesidir (Machlup, 1958: 21). Fakat bütün mucitleri icat yapma konusunda teşvik eden sadece para veya maddi servet değildir. Bununla birlikte, inovasyonun ticarileşmesi ve yaratıcılık başlı başına iki farklı olgudur ve birbirlerini 
etkilemezler. İnsanlık deneyimi göstermiştir ki, patent sistemi ne olursa olsun inovasyon her zaman gerçekleşecektir (Mgbeoji, 2006: 3).

\subsection{Sözleşme veya Sırların Değişimi Teorisi}

"Sırların değişimi” teorisi, mucit ve toplum ve/veya devlet arasında bir pazarlığ varsayar (Mgbeoji, 2006: 3, Oguamanam, 2009) ve gizli bilginin eski sahipliğinden vazgeçilmesi bunun endüstriyel kullanımına geçici bir ayrıcalık koruması verilmesiyle olur. Buradaki önermeye göre, mucitler ve bu alanın girişimcileri buluşları gizli tutarlarsa endüstriyel ilerleme istenen oranda sürdürülemez; bu durumda, yeni teknolojinin genel kullanıma girmesi çok sonra olur; doğal olarak, teknolojik sırlar mucitçileriyle birlikte ölebilir ve toplum açısından kayıp olabilir. Bu nedenle, mucitle pazarlık yapmak toplumun yararınadır ve sırrı gelecek kuşakların kullanımı için açılamaya ikna eder. Bunun da en iyi yolu, buluşu kamuya açıklaması karşılığında ona ayrıcalıklı bir patent hakkı vermektir (Machlup, 1958: 21).

"Sır değişimi" teorisi, tekel kârı özendirmesi olmaksızın yeterince yeni buluş olup olmayacağı sorusundan bağımsızdır; buradaki nokta, bunlar sırları saklamaktadırlar ve toplum bunların açıklanması yoluyla elde edeceği yararı yalnızca bunların basımı karşılığında patent koruması vererek elde edebilir (Machlup, 1958: 24).

Bu teori birkaç noktada sorunludur: İlk olarak, gizliliğin korunduğu yerlerde, mucitler ve endüstri kesimi, ticari sırlar ile yasal bir koruma istemektedir. Gerçekte temel konu şudur: mucitin icadını gizli tutmasına rağmen diğer mucitler bu icadı rastgele bulmuş olabilirler, çünkü inovasyon toplumun ihtiyaçları doğrultusunda ortaya çıkar. Genellikle söylendiği gibi, ihtiyaç, icadın anasıdır. İkincisi, gerçekte mucite verilen tekel ayrıcalığının icadın toplumsal yararına ile eşit olup olmadığı her zaman belirsizdir (Mgbeoji, 2006: 3).

\section{Mülkiyet Kavramına Yaklaşımlar}

Herhangi bir mülkiyet teorisi, fikri mülkiyet haklarını da içerecek şekilde, tüm mülkiyet şekillerini açıklamaktadır. Bu varsayım doğru veya yanlış olabilir. Diğer mülkiyet haklarında olduğu gibi, fikri mülkiyet hakları da bireyler arasındaki ilişkileri göstermektedir. Gayrimenkul hukukundan farklı olarak, fikri mülkiyet hukuku soyut nesneler üzerindeki haklara ilişkindir 
(Drahos, 1996: 1). Diğer bir deyişle, fikri mülkiyet hakları, fikri ürünlere ilişkin haklardır. Fikri ve sınai mülkiyet hakları, patent, faydalı model, endüstriyel tasarımlar, ticari markalar, coğrafi işaretler, telif hakları ve komşu hakları (neighboring rights) ve ticari sırları kapsamaktadır.

Hughes'e göre, fikri mülkiyetin evrensel tanımının başlangıcı, fiziksel olmayan bir mülkiyetten temellenmesi ve bunun değerinin bir fikir ya da fikirlerden kaynaklanıyor olmasıdır. Dahası, bir yenilik unsurunun kesinlikle olmasıdır. Aslında, fikri mülkiyete konu olan nesne ya da şey kimse tarafından bilinmeyecek kadar yeni de olabilir. Yine de yeniliğin kesin olması gerekmez. Önemli olan, fikrin mülkiyeti edinme tarihinde genel olarak bilinmemesi esastır. Herhangi bir 'Şey', mülkiyetleştirme tarihinde toplumsal fikri hayatta genel geçer bir durumda olamaz (Hughes, 1988: 4).

Hughes'e göre, yeni geliştirilen fikirlerin hepsi mülkiyet haklarının konusu olamaz. Hughes bu durumu şu örneklerle betimler: Köpeği daha kısa bir tasmayla dolaştırmak ya da ilk buluşmada Eiffel Kulesi'nin tepesine çıkmak gibi her gün karş1laşılabilecek fikirler fikri mülkiyet haklarına konu olamaz. Tam ters noktada, olağandışı fikirler ya da keşifler de yasal koruma alanının dışında kalır; örneğin cebir, Pisagor teoremi, iki kurgu kahramanı arasındaki romantizm, mimari sütunlar ya da basit algoritma (Hughes, 1988: 6).

Hughes'e göre, fikri mülkiyet hakları kümesiyle, diğer tür mülkiyet hakları kümesi arasındaki belki de en önemli fark, fikri mülkiyetin daima özünde tanımlı bir bitişi, kendiliğinden sona erişi olmasıdır. "Batı toplumunun, miras vergisini yüzde yüz oranında uygulasaydı nasıl farklı olacağını bir düşünün. Bu fark, fikri mülkiyeti güçlü biçimde diğer tür mülkiyetlerden ayırır” (Hughes, 1988: 6).

Donald G. Richards'a göre, TRIPS'in meşruluğunun anlaşılması, mülkiyet ve mülkiyet hakları kavramını ve ikisi arasındaki ilişkiyi ve küresel ekonomide piyasadaki rolünü meşru olarak kabul etme ön kabullerini gerektirir (Richards, 2004: 26). Bu nedenle biz bu bölümde, fikri ürünler üzerindeki hakların korunmasına ilişkin literatürdeki en çok bilinen teorilerin kökenlerine ve geçmiş dönemdeki felsefecilerin mülkiyet üzerine görüşlerini ele alacağız. 


\subsection{John Locke: Emek Temelli Mülkiyet Kavramı}

Locke'nin teorisi, özel mülkiyetin haklılaştırılmasında her bir kişinin (ki bu kişi erkektir) emeğinin ürününe sahip olmasından yola çıkar.

Eğer Tanrı tüm insanlara ortak paylaşımları için toprak verdi ise, herhangi bir kimsenin belirli bir toprak parçası üzerinde özel mülkiyete sahip olması yönünde doğal bir sebep yoktur (Drahos, 1996: 3) (Richards, 2004: 26).

Drahos'a göre, Locke'nin teorisini kullanan araştırmacilar emek ve emek üzerine eğretilemeler üzerinde yoğunlaşmak eğilimindedirler. Drahos fikri mülkiyet teorisi ile ilgili olarak Locke’a geri dönerek bağlantı kurmanın ideolojik meşrutiyet sağlama nedenleri ile çekici bir bağlantısı olduğunu vurgular. Bu nedenle de Drahos, mülkiyet üzerine konuşmalarda Locke'nin güçlü bir totem olarak kaldığını belirtir (Drahos, 1996: 48).

Hettinger'e göre, belki mülkiyet haklarını destekleyen en güçlü sezgi insanların kendi emeklerinin ürünlerine sahip olmasıdır. Bir kimse bir şeyi kendi zekâsı, azmi ve gücüyle üretirse ona bir başkası değil onun sahip olması gerekir. "Niçin bu benim? Çünkü, evet onu ben yarattım. Bu nedenle benim. Bensiz bu şey var olamazdı." Hettinger, Locke'nin versiyonunda mülkiyet haklarının, emek temelinde haklılaştıııldığını belirtir. Bir kişi bedenine sahiptir ve sahip olduğu bu beden ile yaptığı şeylerinde sahibidir, üretilmiş o nesne onun emeğidir. Bir kişinin emeği ve emeğinin ürünü birbirinden ayrılamaz ve mülkiyet hakkı bu ilişkiyi diğer kimselere karşı korur (Hettinger, 1989: 36-37). Locke'nin temel mantığı basittir: Emek benimdir ve kamunun ortak nesnelerine emeğimi kattığımda onlar benim olur (Gordon, 1993: 1544-1545).

Mülkiyet üzerine yazmaya başladığı zaman muhtemelen aklında fikri mülkiyet kavramı olmayan ve dikkatini fiziksel mallardan çok maddi mallar üzerinde yoğunlaştırıp (Drahos, 1996: 46), mülkiyetin gerekçelendirilmesini, emek-temelli olarak açıklaması ile ünlü olan (Drahos, 1996: 46) (Baer, 1995: 262) Locke için özel mülkiyet Tanrı'nın insanlara ortak kullanım amacıyla verilmiş şeylere, kişinin emeğini katması ile haklılaşan bir süreci nitelemektedir. Drahos'a göre ise, Locke'nin mülkiyet analizi kamusal alanın varlığı ile başlar ve bu Tanrı'nın armağanıdır (Drahos, 1996: 49). 
Fakat Hettinger'e göre, daha önemlisi, varsayalım ki, emeğin ürünleri değerlidir ve emek sahibi bu değer üzerinden bir mülkiyet hakkı elde etmektedir. Yani emek sahibi sadece eklediği değer üzerinden bir hak kazanır, nihai ürünün tamamının değeri üzerinden değil. Hettinger, emek ve emek ürünü şey arasında ayrım yapmanın zor olduğunu ama bu ayrımın gerekli olduğunu belirtir (Hettinger, 1989: 37).

Locke, bir nesnenin insan emeği ile üretilmeden önce çok az bir değere sahip olduğunu (Hettinger, 1989: 37) ve ancak "yeryüzünün insan yaşamına yararlı ürünlerinin, onda dokuzunun, emeğin sonuçları olduğunu söyleme[nin] oldukça 1lımlı bir hesaplama" olduğunu belirtmektedir (Locke, 2004: 36-37).

Hughes'e göre, mülkiyetleştirme fikirleri, Locke'un yaklaşımındaki üç önerme ile ele alınabilir: ilk olarak, fikirlerin üretimi bireylerin emeğini gerektirir; ikinci olarak, bu fikirler “yaygın” olandan ayrılmalı ve bu fikrin çıkarılmasıyla bunda bir değer azalması olmamalıdır ve üçüncü olarak, fikirler israf edilmeme koşulunu ihlal etmeksizin mülkleştirilebilmelidir. Çoğu kişi bu önermeleri dolaylı olarak kabul etmektedir. Zaten, fikri mülkiyetin Locke'cu açıklaması dolaysız ve sezgisel bir başvurudur: göründüğ̈ kadarıyla insanlar fikir üretmek için iş yapar ve bu fikirlerin değeri -özellikle burada bir fiziksel unsur olmaması nedeniyleyalnızca bireyin zihinsel “işine” bağlı olur (Hughes, 1988: 8-9).

Hettinger bu noktada şunu sormaktadır: Edebi eserlerin, buluşların ve işletme bilgisinin değerinin hangi oranı entelektüel emeğe aittir? Şayet entelektüel ürünler bizim için değerli ise yazarlar, icatçılar ve geliştiriciler gereklidir ve bu emek çeşidi olmasaydı biz bu ürünleri kullanamaz ve değerlendirmeye tabi tutamazdık. Fakat Hettinger, buradan yola çıkarak da entelektüel ürünlerin değerinin tamamının da entelektüel emeğe atfedilemeyeceğini belirtir. Örneğin tekerlek tümüyle insanlığın [ortak yaratımının] bir değeri olduğundan tekerleğe ait değer sadece ilk yaratıcısına atfedilemez (Hettinger, 1989: 37). Herhangi bir yazarın üretim sürecinde, ilk basılan eserlerden kasıtsız veya tesadüfen yaptığı alıntıların veya benzerliklerin yarattığı sorunları tartıştığı "Copyright as Myth” isimli makalesinde Jessica Littman, "tüm yazarların verdikleri eserler, önceki yazarların çalışmalarından etkilenmiştir” (Litman, 1991: 243) demektedir. 
Hughes'e göre, herhangi bir fikirler kategorisinde mülkiyet hakkına izin verilmemesinin bir nedeni, böyle olması durumunda bu fikirlerin sahiplerine doğru inanılmaz büyüklükte bir refah akışının olacak olmasıdır. Her hayalet hikâyesi anlattığımızda ya da köpek gezdirdiğimizde bir imtiyaz ücreti ödemek zorunda olsaydık, öngörülemez miktarda bir refah bu en yaygın fikirlerin "sahiplerinin” elinde yoğunlaşırdı. Bu genel, günlük hayata dair fikirler jenerik olarak birinin bunlar üzerinde tekel kurmasına yarardı. Bunlar çıkarıldığında günlük olan “yeterince ve iyi” olamazdı (Hughes, 1988: 21).

Hughes'e göre, herhangi bir fikirler kategorisinde mülkiyet hakkına izin verilmemesi sıra dışı fikirler için de geçerlidir. Bu kategori, gene de, iki farklı grup fikri içerir. Birincisi, dünya hakkındaki olguları açıklayan olağanüstü fikirlerdir, Pisagor bağıntısı ya da elektromanyetik kuramı gibi. Elektromanyetik kuramı örneğinde, Yüksek Mahkeme, uzun mesafe iletişim için galvanik akımın kullanımına dair genel fikrin Samuel Morse tarafından tekele alınamayacağına, buna karşın fikrin kendisi tarafından özgün kullanım işleminin tekele alınabileceğine hükmetmiştir (Hughes, 1988: 21, Baer, 1995: 264).

İkinci grup olağandışı fikirler - örneğin mimari sütunlar benzeri gibi fikirler kullanımlarının büyük ölçüde kamuya mal olmuş olması dolayısıyla tekel altına alınamazlar (Hughes, 1988: 22, Baer, 1995: 264).

Kısacası, bazı fikirler, "mülkiyetsizleştirilir". Aslında, bunlar özel mülkiyete konu olabilir, ancak, fikirler toplum için giderek artan bir önemi haiz oldukça bunların kamuya ait olması için baskı da artmıştır. Bir fikir sıra dışı olduğunda, fikre dair haklar özel olarak edinilmiş durumdaysa, toplumun "yeterli ve yeterince iyi” bir sahipliği olmayacağı açıktır (Hughes, 1988: 21). Aynı şekilde Hettinger'e göre, buluş, edebi eser ve genel bir düşünce yaratmak kapalı bir ortamda gerçekleşmez; yani entelektüel aktivite yokluktan yaratılmaz. Entelektüel ürünler aslında sosyal ürünlerdir. Bu nedenle entelektüel ürünlerin değeri insan emeğinin bir sonucu olarak görülse de, özgül bir emek sahibine (veya küçük bir çalışanlar grubuna) ait değildir. Mucit, yazar veya yöneticinin bireysel katkılarını tarihsel / sosyal süreçten ayırmak kolay değildir. Basit bir şekilde, nihai ürünün piyasa değerine sadece emekçinin emeğinin bir değer kattığını öne sürmek başkalarının katkılarını ihmal etmektir (Hettinger, 1989: 38-39). 
Hettinger'e göre, piyasa ancak mülkiyet hakları tanındıktan ve uygulamaya geçildikten sonra çalışmaya başlar. Bu nedenle de sorulması gereken soru şudur: insanın entelektüel tarihinin bir sonucu olarak yaratımda bulunan mucit, yazar ve yönetici ne çeşit mülkiyet haklarına sahip olmalıdır? Bu bağlamda piyasa değeri de diğer üreticilerin eylemlerine veya eylemsizliklerine, alıcıların para talebine, mülkiyet hakları ve sözleşme çeşitleri ile devlet tarafindan kurulan ve uygulanan piyasa ilişkilerine bağlı olan sosyal olarak oluşturulmuş bir olgudur (Hettinger, 1989: 38).

Hettinger'e göre, iki nedenden dolayı emek sahibi bir kimse emeğinin ürününün piyasa değerinin doğal olarak sahibi değildir. Birincisi, piyasa değeri, ürün üreten kişiler tarafından yaratılan bir şey değildir ve emek temelli argüman emeklerinin ürünlerine sadece emek verenlerin hakkı olduğunu vurgular. İkincisi, ilk durum ihmal edilse dahi, emeğin ürünü ile ürünün değerinin piyasa değerleri eşit iken, entelektüel ürünler son yaratıcısına rağmen pek çok insanın emeğinin bir sonucudur ve bu insanlarda ürünün piyasa değeri üzerinden hak iddia edebilirler (Hettinger, 1989: 39).

Hettinger'e göre, eğer emek teorisi emek sahibinin emeğinin ürünleri üzerinde doğal bir hakka sahip olduğunu gösterse bile, bu durum nihai ürünün piyasa değerinin tamamı üzerinde bir hakka sahip olduğunu anlamına gelmez. Bir emekçinin ortaya koyduğu ürününün piyasa değerini almaya hakkı olduğuna ilişkin nosyon sadece bir mittir. Bireysel olarak emekçilerin ortaya koydukları ürünlerin piyasa değerini alabilmeleri bir sosyal politika sorunudur; bu sorun basitçe bir kişinin emeğinin ürünlerine etik olarak sahip olduğu iddiası ile çözülemez (Hettinger, 1989: 39).

Locke'un teorisi işlevini kaybetmiş Orta Çağ otoritesinin siyasi ve ekonomik imtiyazlarını zayıflatmak için bir girişim olmasının yanı sıra İngiltere'de ortaya çıkmaya başlayan kapitalist sınıfa ideolojik meşruiyet sağlamaktaydı (Richards, 2004: 30). Diğer bir deyişle, XVIII. yüzyılın egemen ideolojisinin baskın yanını temsil eden Locke'nin mülkiyet anlayışı, feodal dönemin ekstra-ekonomik "süslerinden" ve yükümlülüklerinden kurtulmuş, mülkiyetin artık "iktisadi” olarak anlaşıldı̆̆ı, ticari metalar üretmek yönünü kapsıyordu ve böylelikle Locke, kapitalist mülkiyet tanımının temellerini atmıştır (Wood, 2007: 182). Locke'nun kuramı emek temelli bir gerekçelendirmeye dayansa da, Locke'un düşüncesinde 
emek, patriarkal hiyerarşik ilişkilerin ücretli işçiye uygulanmasından ibarettir (Wood, 2007: 180) (Richards, 2004: 31). Ayrıca, Locke’un mülkiyet kuramının “doğal haklar” kuramıyla kurulan ilişkisi, kapitalizmin ilkel birikim döneminin karakteristik özelliklerini yansıtırken, günümüzün kimi yazarlarının post-modern dönem diye adlandırdıkları dönemi açıklamaktan uzaktır.

Hughes'e göre, fikri mülkiyetin emek kuramı güçlü ama eksik bir nosyondur ve bu nedenle bir kişilik kuramına da gerek duyulmaktadır. Hughes buna örnek olarak Hegel'in mülkün kişinin kendisinin ifadesi olması önerisini vermektedir (Hughes, 1988: 27-28).

\subsection{Hegel: Dünyanın Kontrolü}

Locke'un mülkiyet modeline en güçlü alternatif, bir seçenek kişilik açıklamasıdır. Bu tür bir açıklama, mülkiyeti, kendini gerçekleştirme, kendini ifade etme ve tekil bir birey olarak tanınma ve kişisel onur için eşsiz ya da özellikle uygun bir mekanizma olarak varsayar (Hughes, 1988: 28).

İçinde yaşadığı toplumun giderek artan ticarileşmesinin farkında olan Hegel'in düşünsel yapısını belirleyen etkenin arkasında toplumun ekonomik ve siyasi örgütlenmesinin kesinlikle burjuva karakterde olması yatmaktadır (Richards, 2004: 39). Bu nedenle Hegel için mülkiyet, genç Marx’ın “kendi”nin ifadesi olarak emeği kavramasına benzer şekilde, “kendi”nin ifadesi olarak tasarımıdır (Baer, 1995: 264). Hegel felsefesinin kalbinde, kendisinin zor kavramları olan insan iradesi, kişilik ve özgürlük yer alır. Hegel için, bireyin iradesi bireyin varlığının özüdür, dünyada sürekli bir gerçeklik (Wirklichkeit) araştırması ve etkinlik Hegel'in bireyinin zihni yapısındaki elementler hiyerarşisinde, irade en yüksek yerde konumlandırılmıştır (Hughes, 1988: 28). Hatta Hegel için mülkiyet dünyanın kontrolünü ele geçirmede bireysel girişimlerin korunmasında önemli bir alettir (Hughes, 1988: 33).

Hegel için, bireysel ilginin çekici yanı "pratiksel özgürlükle" ilgilidir; Hegelyen anlamda özgürlük “zorunlulukların gerçekleşmesidir” (Richards, 2004: 37). Hegel, insan iradesi, özgürlük ve mülkiyet arasındaki ilişkileri şu şekilde açıklar: 
"Hukuk, her şeyden önce, özgürlüğün kendi kendisine verdiği dolaysız mevcudiyettir. Özgürlük, bunu, yine dolaysız bir tarzda, aşağıdaki şekillerde yapar:

a) Zilyetlik, yani mülkiyet: özgürlük, burada, genel olarak soyut iradenin ya da başka bir deyişle, yalnız kendi kendisiyle ilişkide olan bir özel şahsın özgürlüğüdür;

b) Kendi kendisiyle farklılaşarak başka bir şahısla ilişkiye giren şahıs (bu iki şahıs birbirleri için ancak mülkiyet sahibi olarak vardırlar): bunların kendiliğinde (virtüel olarak) mevcut aynılıkları, mülkiyetin birinden ötekine, karşılıklı rızalarıyla ve haklarının muhafazası şartıyla, geçmesiyle gerçeklik kazanır. Böylece mukavele ortaya çıkar;

c) Kendi kendisiyle ilişkisi içinde farklılaşmış_ (b) deki anlamıyla, yani başka bir şahısla ilişkisi içinde değil, (a) daki anlamıyla, yani kendi kendisiyle ilişkisi içinde farklılaşmış_ irade, kendiliğinde ve kendisi-için varlığı ile tezat halinde olan iradedir, yani haksızlık ve cürümdür." (Hegel, 1991: 61).

Hegel'e göre, ancak şahsiyet nesneler üzerinde bir hak sağlar ve özgür olmayan, şahsiyeti olmayan, hiçbir hakkı olmayan bir şeydir (Hegel, 1991: 63). Bu bağlamda Hughes, Hegel'de kişilik ve mülkiyet arasında açık uçlu bir bağlantının var olduğunu belirtir (Hughes, 1988: 31, Baer, 1995: 264). Bir kişinin herhangi somut bir nesneden bireysel çıkar ileri sürmesi, kişilik açıklamasının ileri savları barındırıyor olması anlamına gelir. Bu, Virginia Woolf'un bir odanın kendisine ait olmasını ileri sürmesine izin verirken, XIV. Louis'in de Versay'da kendine ait 2697 odayı ileri sürmesine de izin verir (Hughes, 1988: 36). Baer'e göre bu durum Hegel'in kişilik temelli mülkiyet teorisinin zayıflığı olarak algılanmaktadır (Baer, 1995: 265).

Hegel'e göre, entelektüel nitelikler, bilim, sanat, hatta dinî yetkiler (vaaz, âyin, dua, takdis), icatlar, vs. tıpkı alınıp satılan şeyler gibi, sözleşme konusudurlar. Bir sanatçının, bir bilginin, vs. sanatına, bilimine, vaaz vermek, âyin yönetmek, vs. ehliyetine hukuken sahip olup olmadığı, yani bu gibi becerilerin birer şey olup olmadığı sorulabilir. Hegel, bu tür kabiliyetlere, becerilere, ehliyetlere, vs. "şey" demekte tereddüde düşülmemesi gerektiğini belirtir (Hegel, 1991: 63). Hegel için fikri mülkiyet fiziksel mülkiyetle analoji kurularak açıklanmalıdır. Aslında, fiziksel mülkiyetle analoji kurulması Hegel'in irade ile bağlantılı olarak resmettiği kişilik ve zihinsel niteliklerde bozulmaya yol açabilir (Hughes, 1988: 3). 
Kişilik için temel, yasal kavram olarak bireyin "kişilik" olmasıdır. "Kişilik" bireyin kamudaki görünümüdür ve fiziksel özelliklerini, özgün tavırlarını ve tarihini de içerir (Hughes, 1988: 35). Bu nedenle Baer, kişiliğin aynı zamanda toplum tarafından da onaylanması ve doğrulanmasının veya Hegel'in terimi ile “tanınması”nın da gerekli olduğunu belirtir (Baer, 1995: 264).

Bir kişi mülkiyetini ileri sürer ve diğerleri de onu mülkle birlikte tanımlar. Bu durumda, yaratıcı, özgün bir kişilik yarattığı (ifade etmekten ziyade) için mülkiyeti iddia eder. $\mathrm{Bu}$ “dışsallaştırma” Hegel kuramına göredir. Hegel, bireyin mülkiyet haklarını tanımanın bireyi kişilik olarak tanıma anlamına geldiğini tartışmaktaydı. Bu açıklama dışsallaştırma ${ }^{2}$ bağlantısına da uygulanır: eğer $X$ bir patente sahipse, insanlar onu belirli bir kişi olarak tanıyacaktır - eşsiz bir icadın mucidi (Hughes, 1988: 37).

Fikri mülkiyetle ilgili büyük kuramların -emek ve kişilik - her ikisi de kendi güçlü ve zayıf yanlarına sahiptirler. Emek açıklaması, fikrin başlangıcında emeğin içerilmesiyle ilgili noktaya açıklık getirmemektedir; kişilik kuramı, toplumun kişilik ifadesi olarak tanımlayabileceği unsurları içermeyen değerli buluşlara uygulanabilir değildir. Kişilik açıklaması yabancılaşmayı meşrulaştırmada güçlük çeker, emek açıklaması Locke’un atıksızlık koşulu etrafinda dolaşmaktadır (Hughes, 1988: 51).

Aynı zamanda, iki açıklama, meşruiyet sağlanmak için sıklıkla başvuruldukları mülkiyetten ziyade fikri mülkiyet açıklamasına daha uygun görünmektedirler. Lock'cu emek kuramı daha kolaylıkla uygulanır, çünkü genel fikirler tükenmez gibi gözükmektedir. Hegelci kişilik kuramı fikri ürünlere daha kolay uygulanır, çünkü en teknik olanı bile bireyin zihni sürecinin sonucudur. Bireyin tanınmasını güven altına almada mülkiyet hakkını kullanan Hegel'in ilgisinde fikri mülkiyet hakları bu noktada güçlü bir enstrümandır, çünkü şey birey tarafindan zapt edilmemiştir, bundan ziyade bireyin ürünüdür (Hughes, 1988: 51).

\footnotetext{
${ }^{2}$ Hegel dışsallaştırma kavramını şu şekilde açıklamaktadır: "Şahıs, İde olarak var olabilmek için, özgürlüğünü bir dış alana taşıyıp yaymak zorundadır. Şahıs, henüz tamamen soyut nitelikte olan bu ilk determinasyonunda, kendiliğinde ve kendisi-için sonsuz irade olduğuna göre, onun özgürlük seferini oluşturabilecek olan bu ondan ayrl şey, ondan dolaysızca farklı ve ayrllabilir şey olarak belirlenmiştir. ” (Hegel, 1991: 62-63)
} 
Toplumsal bir kurum olan fikri mülkiyeti açıklamak için büyük genellemeler aramanın iki nedeni vardır. Birincisi, “emek” ve "kişilik", "mülkiyet”e kıyasla daha genel başvurulardır. Tam döngüye dönmek için, çalışma hakkı ve bireyin kendini ifade etme hakkı mülkiyet hakkından daha etkili bir uyarıcıdır. İkinci neden, tüm toplumsal kurumlara uygulanabilir, genelleştirilen nitelendirmelerden kaçınamayız. Tek yolumuz bu genellemelerle doğrudan yüzleşmek ve bunları bilinçli bir biçimde birleştirmektir (Hughes, 1988: 51). ${ }^{3}$

\subsection{Faydacı Yaklaşım}

Yeni ürünlere teşvikler sağlamayı temel alan faydacılık argümanı, entelektüel mülkiyet haklarını haklılaştırmaya yönelik olarak kullanılan en güçlü ve en yaygın (Hettinger, 1989: 47) yöntemdir. Donald G. Richards'ın (Richards, 2004: 31) da belirttiği gibi, özellikle günümüzde, neoklasik iktisadi yapının temel bir felsefi söylem tarafından savunulması faydacılık kavramıyla sağlanmaktadır: Fayda maksimizasyonu piyasa sisteminde ajanların etkin bir kaynak tahsisine ulaşmasını sağlamada yol gösterici işlevi olan bir varsayım olarak ele alınır. Aynı zamanda faydacı felsefenin, mülkiyeti haklılaştırmak için sağlam gerekçeler sunması şaşırtıcı olmadığı gibi, piyasa tarafından daha büyük bir eşitliğin sağlandığı toplumsal düzenlemelerinde güçlü şekilde meşrulaştırılmasında önemli roller oynaması yadırganmamalıdır.

Hettinger, faydacı yaklaşıma örnek olarak ABD Anayasasının "bilimsel ilerleme ve yararlı sanatları teşvik" eden patent ve telif hakları ile ilgili maddesini örnek olarak verir (Hettinger, 1989: 47). ${ }^{4}$

Faydacı yaklaşıma göre, değerli entelektüel çalışmaların yaratılmasını desteklemek için, fikir emekçilerinin çalışmaları, mülkiyet hakkı tanınarak ödüllendirilmelidir; telif hakları, patentler ve ticari sırlar, mülkiyet hakları koruması içermiyor ise fikir üreticilerinden optimal

\footnotetext{
${ }^{3}$ Hettinger, "Entelektüel emeği ödüllendirmeye ve teşvik etmeye yönelik uygun alternatif seçenekler hakkında daha açık ve yaratıcı düşünmeliyiz" diyerek bu görüşü benimsemektedir (Hettinger, 1989: 52).

${ }^{4}$ Faydacı yaklaşıma ilişkin tarihin daha erken dönemlerinden bir tartışmayı Aristoteles'in Politika isimli eserinde görmekteyiz: “Aristo, ilk şehir plancıs Miletos'lu Hippodamos'un ülkeleri için yararlı buluşlar yapanlara şeref ve ödüller verilmesi önerisini eleştirir. Aristo'ya göre göze ve kulağa hoş gelen bu öneri çok sakıncalıdır çünkü bu perde arkasında dalaverelere yol açacak ve bazı durumlarda da anayasal yaşaylşı bozacaktır. Aristo'ya göre kamu yararına diye insanlar toplumu ve yasaların ylkacak önerilerde bulunabilirler." (Aristoteles, 1983: 48$52)$.
} 
düzeyde sosyal bir çıktı yaratması da beklenemez. Eğer rakip kişi ve şirketler basit bir şekilde kitapları, filmleri ve müzikleri kopyalayabiliyorlarsa ve başkalarının icatlarını ve iş tekniklerini izinsiz olarak alabiliyorlarsa, bu çeşit ürün ve teknikleri geliştirmek isteyenler için gerekli olan zaman, enerji ve parayı harcamaları doğrultusunda yeterli teşvik sağlamaz (Hettinger, 1989: 47-48).

Hettinger'e göre, faydacı yaklaşım fikir ürünlerinin üreticilerine değil kullanıcılarına (tüketicilere) odaklanır. Bu yaklaşımda üreticilere verilen mülkiyet hakları, yeterli fikri ürünün ve bu ürünlere dayalı diğer sayısız ürünlerin kullanıcılar tarafından kullanılabilmesini sağlamak için gerekli görülmektedir. Bu bağlamda üreticilere verilen mülkiyet hakları sadece bir araçtır (Hettinger, 1989: 48).

Hettinger'e göre, faydacı yaklaşım paradoksal bir özellik sergiler. Çünkü faydacı yaklaşım, mevcut durumu korur ve üretimi artırmak amacıyla fikri ürünlerin kullanımını gerekli görürken bu da gelecekteki durumu ve yeni fikri ürünlerin kullanımını kısıtlayan bir hakkı doğurur (Hettinger, 1989: 48).

Hettinger'e göre, eğer fikri mülkiyet hakları faydacı bir argüman ile haklılaştırılıyor ise, bu durumda fikri ürünlerin üretimini teşvik etmek için daha teşvik edici alternatif yöntemler, entelektüel çalışmaların hükümetçe desteklenmesi ve kamu mülkiyetine alınması olabilir. Hükümet zaten temel araştırma ve geliştirme çalışmalarını desteklemektedir ki bu araştırmaların sonuçları da kamu mülkiyeti / malı özelliği kazanmaktadır (Hettinger, 1989: 48).

\subsection{Marx: Toplumsal İlişki}

Kapitalist piyasa ekonomisinin en temel kurumlarından biri olan özel mülkiyet, hem sistemi korur hem de sistemin kendisini yeniden üretmesinin temel aracıdır. David Harvey'in Marx’a dayanarak belirttiği gibi, "kapitalist üretim özel mülkiyet kurumunu (birçok feodal kurumu yıktığı gibi) yıkacak durumda değildir, çünkü kendi varlığı üretim araçlarının özel mülkiyetine dayanır" (Harvey, 2006: 168) ${ }^{5}$ ve iktisadi sistemi ayakta tutan, üzerine inşa edildiği mülkiyet sisteminin dayanıklılığıdır (Harvey, 2006: 185). Bu bağlamda “özel mülkiyetin

\footnotetext{
${ }^{5}$ Ellen Meiksins Wood'a göre ise, "kapitalistin özel mülkiyetini koruması; onun üretimi ve sömürü düzenini denetlemesine olanak sağlayan gücünü” gösterir ( Wood, 2008: 37).
} 
tekelci gücünü gerçekleştirecek sayısız taktik”lerden (Harvey, 2006: 1175-176) biri olan fikri mülkiyet hakları, teknoloji sahibine başkalarının bu teknolojiyi kullanmasını yasaklamasının yanında kullananlardan bir ödeme talep etmesinin de aracıdır.

Görünürde teknolojiye ilişkin mülkiyet hakları, teknolojik kalkınmayı teşvik etmek amacıyla mucit ve devletlerden gelen baskılar sonucu ile yaratılmış gibi görünse de David Harvey'in doğal kaynaklar üzerine yaptığ 1 tespiti genelleştirirsek şunu ifade etmemiz mümkündür: fikri mülkiyet "üzerinde denetimi arttıracak teknolojik değişiklikler, uygulanabilmeleri yeni toplumsal ve yasal biçimler (yeni işbölümü, yeni mülkiyet geliri kavramları ve benzeri) gerektirebilir" (Harvey, 2006: 185) ve bu durum kapitalist üretimin mantığıdır.

Neoklasik iktisatçılara göre özel mülkiyet kavramının gelişmesi zamanla entelektüel ürünler üzerinde de mülkiyet kavramının gelişmesini sağlamıştır. Çünkü "burjuva ekonomi politiği, üretimi [ve diğer kapitalist kategorileri] özel toplumsal belirlenimlerinden soyutlayarak incelediği için kapitalist üretim ilişkilerini evrenselleştirir" (Wood, 2008: 38) Oysa "her kavramın bir tarihi vardır" (Deleuze ve Guattari, 1993: 25) ve dolayısıyla Marx'ın diliyle ifade edersek entelektüel mülkiyetin tarihi "gerçekte modern sermayenin oluşumunun tarihidir" (Marx, 2003a: 174). Bu fikirler gelişim sürecinin dayatması değil, aslında Polanyi’nin de vurguladığı gibi kapitalizm ile birlikte her alanın metalaşma sürecinin bir sonucudur. ${ }^{6}$

James Boyle’ye göre, “ücretli-emek ilişkisinin 1900’ların endüstriyel toplumunda yaptığının benzerini, bilgi toplumunda fikri mülkiyet ve kavramsal komşuları üstlenebilir" (Boyle, 1996: 13). Pek çok yazar ve özellikle çağımızdaki kültürel gelişmelerdeki incelemeleri ele alan yazarlar için günümüzdeki gelişmelerin açıklanmasında FMH'nın rolü büyüktür ve çağımızda bir anlamda başlangıç olarak "meta" değil "bilgi” ele alınmalıdır.

Çağdaş Marksistler fikri mülkiyeti sosyal bir ilişki olarak düşünürler (Jessop, 2010) bunu da örneğin Marx'ın E.G. Wakefield'in yaptığı çalışmalar üzerine söylediği “sermayenin

\footnotetext{
${ }^{6}$ Ayrıca Bkz. "Kapitalizmin mantığı bizi çevreleyen her şeyin metalaşmasıdır.” (Rikowski, 2006: 406).
} 
bir şey olmayıp, şeylerin aracılığı ile kişiler arasında kurulan toplumsal bir ilişki olduğu” (Marx, 1986: 786) cümlesine dayandırırlar.

Marx ve Engels, bilgi, bilim ve mülkiyet kavramları üzerinde sıkça durmalarına rağmen sınaî ve fikri mülkiyet haklarına çok az değinmişlerdir. Marx ve Engels'in yazılarında her ekonominin bilgi ekonomisi olduğu yönünde bir tartışma vardır. Ayrıca doğanın güçleri ile karşılaştırıldığında bilimin kolektif çalışma ve evrensel üretici güç olduğunu savunurlar (Jessop, 2010).

Küreselleşmiş dünyada, ekonomilerin içine girdiği krizden çıkışta sistemin düzenleyici kurumları, yeni teknolojilerin ekonomideki ağırlığının hissedilmesiyle yeni gelişen bu dijitalleşmiş mallar ve kültürel dünyanın yeniden üretim koşullarının sermayenin istekleri doğrultusunda düzenlenmesi amacıyla FMH'yı gündeme getirmiştir. Marx'ın, "Ne zaman sanayi ve ticaretin gelişmesi, örneğin sigorta şirketleri ve benzerleri gibi yeni biçimler yaratmışsa, hukuk, her seferinde, bu biçimleri, şaşmaz bir biçimde, mülkiyetin elde ediliş tarzları içinde birleştirmek zorunluluğunda olmuştur" (Marx, 1992: 109) tespiti günümüzün küreselleşmiş ve dijitalleşmiş “Risk Toplumu” (Beck, 2011) da meta haline gelen bilginin de FMH düzenlemeleriyle dolaşım ağı içerisine dâhil edilmesine uygundur.

Genç Marx 1844 yılındaki erken dönem yazılarından başlamak üzere bilimsel faaliyet ile üretim süreci arasındaki ilişkinin toplumsal yönüne yani bilginin kamusallığına vurgu yapar:

"Benim etkinliğim bilimsel vs. ise ve ben bu etkinliğe başkaları ile dolaysız ortaklık biçiminde çok seyrek girişebilsem bile, insan olarak davrandığım için toplumsal sayılırım. Sadece etkinliğimin gereci - düşünürün kendi etkinliğini sayesinde yürüttüğü dil gibi - bana toplumsal ürün olarak verilmekle kalmamıştır ama benim kendi öz varoluşum da toplumsal etkinliktir; sonuç olarak kendimi getirdiğim durum da, toplum için ve toplumsal varlık olarak kendimin bilinci ile kendimi getirdiğim durum da toplumsal etkinliktir” (Marx, 1976: 174).

Perelman'a göre, entelektüel mülkiyet, Marx'ın evrensel emek dediği yeni tür mallara dayalı ürünlerin dönüşümünü temsil etmektedir. Evrensel emek, değeri azalmadan defalarca kullanılabilen emektir (Perelman, 2003: 305). Marx, zihinsel emeğin ürününe ilişkin olarak Artı-Değer Teorileri isimli eserinde şunları belirtmektedir: 
“Zihinsel emeğin ürünü - bilim - her zaman değerinin çok altında bir yerde durur; çünkü onu yeniden-üretmek için gerekli emek-zamanının, ilk üretimi için gereken emek-zamanı ile hiçbir ilişkisi yoktur. Örneğin bir okul çocuğu, iki terimli denklem teoremini bir saatte öğrenebilir” (Marx, 1998: 334).

Perelman, Marx'a göre entelektüel malların, toprak ve pek çok maldan farklı olarak rekabetçi bir özellik sergilemediğini, Marx’tan yaptığı şu alıntı ile göstermektedir (Perelman, 2003: 305):

"Bir elektrik akımı alanında manyetik bir ibrenin sapma yasası, ya da çevresinde elektrik akımı dolaşan bir demirin mıknatıs özelliğini kazanacağı yasası bir kez bulununca, artık bir kuruş bile harcamaya neden olmazlar" (Marx, 1986: 400).

Perelman'a göre, bilim ve bilgi kullanıldıkça daha değerli hale geldiklerinden metakamu mallarıdır (Perelman, 2003: 305).

Bilimin üretim sürecinde giderek artan önemi değer yasası için ciddi bir çelişkiyi göstermektedir (Perelman, 2003: 305).

“Emek zamanı - emeğin salt niceliği - sermaye tarafından tek belirleyici öğe olarak konduğu ölçüde, doğrudan emek ve üretimin - kulanım-değerlerinin yaratılmasının - belirleyici ilkesi olarak niceliği kaybolur ve nicel bakımdan daha küçük bir kısma indirgenmiş, nitel bakımdan da, bir yönü ile genel bilimsel emek, fizikî bilimlerin teknolojik kullanımı karşısında, öteki yönü ile genel üretimde toplumsal yapılanmadan oluşan genel üretken güç karşısında, vazgeçilmez olmakla birlikte, daha aşağıya çekilmiş olur - genel üretken güç ise toplumsal emeğin (tarihsel ürün olmasına karşın) doğa vergisi olarak ortaya çıkar. Böylece, sermaye [kapitalizm], üretime egemen biçim olarak kendisini sonlandırmaya çalışır” (Marx, 2003b: 170).

Gorz 'da Perelman gibi, Adam Smith'ten bu yana değer kaynağı olarak kabul edilen basit soyut emeğin yerini karmaşık emeğe bıraktığını belirtir ve ürün biriminin zaman birimiyle çarpımıyla ölçülebilen maddi üretim emeğinin yerini klasik ölçü birimleriyle ölçülemeyen 
maddesiz, emeğe bıraktığını savunur ve üretim sürecindeki değişimin erken dönemlerde Marx tarafından da zaten tespit edildiğini öne sürer (Gorz, 2011: 11):

“Canlı emeğin nesneleşmiş emek karşılığında değişimi; yani toplumsal emeğin sermaye ve ücretli emek karşıtlığı halinde konumu - değer ilişkisinin ve değere dayalı üretimin son gelişmesidir. Büyük sanayinin gelişmesi ölçüsünde, gerçek servetin yaratılması, emek zamanından ve kullanılmış emek niceliğinden daha çok, emek zamanı boyunca harekete geçirilen aracıların gücüne bağlıdır. Bu aracıların gücünün - onların etkili gücünün - onları üretmek için harcanan doğrudan emek zamanı ile hiçbir ilişkisi yoktur; daha çok bilimin genel düzeyine ve teknolojinin gelişmesine, ya da bilimin üretime uygulanmasına bağlıdır. ( $\mathrm{Bu}$ bilimin, özellikle fizik bilimlerin, onunla birlikte bütün öteki bilimlerin gelişmesi, gene maddi üretimin gelişmesi ile orantılıdır) (Marx, 2003b: 174).

"Emek-zamanından tasarruf, serbest zamanın, yani bireyin tam gelişmesi için zamanın artması demektir ve bu da gene en büyük üretken güç olarak emeğin üretken gücü üzerinde etkisini gösterir. $\mathrm{Bu}$ tasarruf doğrudan üretim süreci açısından bakıldığında sabit sermaye üretimi olarak görülebilir; bu sabit sermaye insanın kendisidir" (Marx, 2003b: 180).

Bilgi ve güç ilişkisi, egemen kapitalist sistemin doğasında vardır ve tezimizin genel çerçevesini ilgilendirdiği ölçüde FMH ve TRIPS arasındaki ilişkiler düşünüldüğünde artıkdeğerin ve değerin ölçülebilmesi tartışmalarında yeni bir kapitalist aksiyomatiğin geliştirilmesi gerekmektedir. Yukarıda Marx'dan yaptığımız alıntılardan da görülebileceği gibi Marx özellikle Grundrisse'de bilgi konusunu incelerken bunu ele almıştır.

Tartışmalara günümüzden katılan Deleuze ve Guattari ise kapitalizmin aksiyomatiğinin değişebileceğini ve değişmesi gerektiğini vurgularlar:

"Kapitalizmin, özünde veya üretim tarzında endüstriyel olduğu doğruysa da, o sadece tüccar kapitalizmi olarak işler. Özünde hısımsal endüstriyel sermaye olduğu doğruysa da, sadece ticari ve finansal sermaye ile kurduğu ittifak sayesinde işler. Belirli bir anlamda, bütün sistemi ve arzu yatırımını elinde tutan şey bankadır. Keynes'in katkılarından bir tanesi, arzuyu para sorununa yeniden davet etmekti; Marksist analizin gereksinimlerine sunulması gereken şeyde işte budur. Marksist ekonomistlerin, bankacılık uygulamalarına, finansal işlemlere ve 
kredi parasının özgül dolaşımına yeterli önemi vermezken (ki Marx'a, Marksist para kuramına dönüş anlamına gelecektir), üretim tarzına ve Kapitalin birinci bölümünde bulunabilecek genel eşdeğer olarak para teorisine dair düşüncelerde sıklıkla zaman kaybetmesi işte bu yüzden talihsizliktir" (Deleuze ve Guattari, 2012: 306).

FMH ile özellikle geleneksel bilginin kapitalist üretim süreci içerisine çekilmesi ve üretim sürecinde artan dijitalleşme, enformasyon ekonomisinin gelişmesi sonucu "öncelikle, hem bireysel hem de kolektif anlamda gittikçe daha nitelikli ve karmaşık hale gelen emek, basit ve hesaplanabilir niceliklere indirgenemez. İkinci olarak ise, giderek finans sermaye biçiminde açığa çıkan ve devlet kurallarının içine gömülmüş olan sermaye, gittikçe yapaylaşmakta, manipülatif bir nitelik kazanmakta ve dolayısıyla daha soyut hale gelmekte, ekonomik çevrimin farklı alanları (üretim, yeniden üretim, dolaşım ve gelir bölüşümü) arasında daha fazla dolayım ilişkisi kurmaktadır. Fakat tüm bunlar tarih öncesidir. Postmodern dönemdeki küresel piyasada, ölçme sorunu kendisine bir yer bulamaz" (Negri, 2005: 89).

FMH ile geleneksel bilginin ve toplumsal kültürün üretimlerinin kapitalist üretim sürecine aktarımı ile şeyleştirilmesinin ölçülebileceğini söylemek, Deleuze ve Guattari’nin kavramları ile söylersek tarihi burjuvaziye göre okumaktır: "Tarihi sınıf çatışması yoluyla okumak, onu kod çözümü yapan ve kodu çözülmüş sınıf olarak burjuvaziye göre okumaktır. Kodlarla mücadeleye önayak olduğu ve akımların genel kod çözümüyle iç içe olduğunca tek sınıf odur" (Deleuze ve Guattari, 2012: 337). Üretim uzmanlaştıkça Shiva'nın da doğru bir şekilde belirttiği gibi “artık [değer] bir mit haline gelir" (Shiva, 1998: 43).

\section{Sonuç}

Mülkiyet hakları ve konumuz çerçevesinde fikri mülkiyet haklarının özel alana mı yoksa kamusal alana mı ait olması gerektiği üzerine tartışmalar gelecekte de devam edecektir. Bireysel yeteneklerin ve çalışmaların sonucunda geliştirilen ürünlerin fikri mülkiyet haklarının korunmasının rekabeti teşvik ederek ekonomide yeniliklerin önünü açacağı bir gerçektir ve tarihsel bir uç örneği olarak Thomas Edison karşımıza çıkmaktadır. Yetenekleri ve çalışmaları sonucunda fikri haklarının korunmasını talep etmeyen ve sürekli yeni buluşlara imza atan ve yeniliklerini kamuya armağan eden Nicola Tesla ise diğer bir uç örneği temsil etmektedir. Her 
iki bilim adamı da insanın ve insanlığın olanaklarının, yeteneklerinin gelişmesine katkı sunmuş kişilerdir. $\mathrm{Bu}$ anlamda denebilir ki insanlığın yeteneklerinin gelişmesine katkıda bulunan yeniliklerin özel alana hapsedilmesi yerine kamunun kullanımına sunulması daha yerindedir.

\section{Kaynakça}

Aristoteles, Politika, çev. Mete Tunçay, Remzi Kitabevi, Ankara, 1983.

Baer, W. Karen, "A Theory of Intellectual Property and the Biodiversity Treaty", 21 SYRACUSE J. INT’L L \& COM., 259, 1995.

Beck, Ulrich, Risk Toplumu: Başka Bir Modernliğe Doğru, çev. Kâzım Özdoğan ve Bülent Doğan, İthaki, İstanbul, 2011.

Boyle, James, Shamans, Software, \& Spleens: Law and the Construction of the Information Society, Harvard UP, Boston, MA, 1996.

Deleuze, Gilles ve Guattari, Felix, Felsefe Nedir?, çev. Turhan Ilgaz, YKY, İstanbul, 1993.

Deleuze, Gilles ve Guattari, Felix, Anti-Ödipus: Kapitalizm ve Şizofreni, Cilt I, çev. Fahrettin Ege, H. Erdoğan ve M. Yiğitalp, BS Yayınları, İstanbul, 2012.

Drahos, Peter, A Philosophy of Intellectual Property, Dartmouth Publishing Company, England, 1996.

Gordon, J. Wendy, “A Property Right in Self-Expression: Equality and Individualism in the Natural Law of Intellectual Property”,YALE L. J. 102, 1993.

Gorz, André, Maddesiz, çev. Işık Ergüden, Ayrıntı Yayınları, İstanbul, 2011.

Harvey, David, Sosyal Adalet ve Şehir, çev. Mehmet Moralı, Metis Yayınları, İstanbul, 2006.

Hegel, Georg Wilhelm Friedrich, Hukuk Felsefesinin Prensipleri, çev. Cenap Karakaya, Sosyal Yayınlar, Ankara, 1991.

Hettinger, C. Edwin, “Justifying Intellectual Property”, Philosophy and Public Affair, vol. 18, No. 1, 1989.

Hughes, Justin, “The Philosophy of Intellectual Property”, Georgetown University Law Center and Georgetown Law Journal, 77 Geo. L.J. 287, 1988.

Jessop, Bob, "Intellectual Property Rights", Erişim http://www.dimeeu.org/files/active/0/Jessop1.pdf, 21.4.2010.

Latouche, Serge, Dünyanın Batılılaşması, çev. Temel Keşoğlu, Ayrıntı Yayınları, İstanbul, 1989. 
Litman, Jessica, "Copyright as Myth”, University of Pittsburgh Law Review, cilt: 53, 1991.

Locke, John, Hükümet Üzerine İkinci İnceleme, çev. Fahri Bakırcı, Babil Yayıncılık, Ankara, 2004.

Machlup, Fritz, “An Economic Review of the Patent System”, Study No. 15 of the US Subcommittee on Patents Trademarks and Copyrights, 85th Congress, 2d Session, 1958.

Marx, Karl, 1844 Elyazmaları, çev. Kenan Somer, Sol Yayınları, Ankara, 1976.

Marx, Karl, Kapital, Cilt I, çev. Alaattin Bilgi, Sol Yayınları, Ankara, 1986.

Marx, Karl, Artı-Değer Teorileri, Cilt I, çev. Yurdakul Fincancı, Sol Yayınları, Ankara, 1998.

Marx, Karl, Alman İdeolojisi, çev. Sevim Belli, Sol Yayınları, Ankara, 1992.

Marx, Karl, Grundrisse, Cilt I, çev. Arif Gelen, Sol Yayınları, Ankara, 2003a.

Marx, Karl, Grundrisse, Cilt II, çev. Arif Gelen, Sol Yayınları, Ankara, 2003b.

Mgbeoji, Chibuzo Ikechi, "Beyond Patents. The Cultural Life of Native Healing and the Limitations of the Patent System", 2005, s. 3.

Mgbeoji, Chibuzo Ikechi, Global Biopiracy: Patents, Plants And Indigenous Knowledge Law and Society, UBC Press, Toronto, 2006.

Negri, Antonio, “Değer ve Duygulanım”, çev. Münevver Çelik, Conatus Çeviri Dergisi, Sayı 4, Temmuz-Ekim 2005.

Oddi, A. Samuel, "TRIPS-Natural Rights and a 'Polite Form of Economic Imperialism'," Vanderbuilt Journal of Transnational Law 29, 1996.

Oguamanam, Chidi, "Beyond Theories: Intellectual Property Dynamics in the Global Knowledge Economy”, 2009.

Richards, G. Donalds, Intellectual Property Rights and Global Capitalism: The Political Economy of the TRIPS Agreement, M.E. Sharpe Publication, New York, 2004.

Rikowski, Ruth, “A Marxist Analysis of the World Trade Organisation's Agreement on TradeRelated Aspects of Intellectual Property Rights", Policy Futures in Education, Volume 4, Number 4, 2006.

Shiva, Vandana, Staying Alive: Women, Ecology and Survival in India, Zed Books, London, 1998.

Perelman, Michael, "Intellectual Property Rights and the Commodity Form: New Dimensions in the Legislated Transfer of Surplus Value", Review of Radical Political Economics, say1:35, 2003. 
FSECON YAYLA, Y. (2020), "Fikri Mülkiyet Hakları ve Mülkiyete İlişkin Teorik Yaklaşımlar", Fiscaoeconomia, Vol.4(2), 287-

Polanyi, Karl, Büyük Dönüşüm, çev. Ayşe Buğra, İletişim Yayınları, İstanbul, 2007.

Wood, Ellen Meiksins, Kapitalizmin Arkaik Kültürü, çev. Oya Köymen, Yordam Kitap, İstanbul, 2007.

Wood, Ellen Meiksins, Kapitalizm Demokrasiye Karşı, çev. Şahin Artan, Yordam Kitap, İstanbul, 2008. 